\title{
Effects of harmaline on cell growth of human liver cancer through the p53/p21 and Fas/FasL signaling pathways
}

\author{
BIN XU, MINPENG LI, YUAN YU, JUN HE, SIQIN HU, MENG PAN, SHIFENG LU, \\ KE LIAO, ZHUANG PAN, YANXUN ZHOU and JIYE ZHU
}

\begin{abstract}
Department of Liver Surgery, The First Affiliated Hospital of Guangxi University of Traditional Chinese Medicine, Nanning, Guangxi 530023, P.R. China
\end{abstract}

Received April 21, 2016; Accepted February 23, 2017

DOI: $10.3892 / \mathrm{ol} .2017 .7495$

\begin{abstract}
The effects of harmaline on the viability and apoptosis of human liver carcinoma were investigated in vitro. HepG2 cells were treated with harmaline $(0-10 \mu \mathrm{M})$, and the proliferation and apoptosis of HepG2 cells were investigated using an MTT assay and flow cytometry, respectively. The protein expression of cellular tumor antigen p53 (p53), cyclin-dependent kinase inhibitor 1 (p21), tumor necrosis factor receptor superfamily member 6 (Fas), Fas ligand (FasL) and caspase- 8 was subsequently measured using western blotting. In addition, an ELISA was used to analyze caspase-8/3 activity. Harmaline significantly increased p53, p21, Fas and FasL protein expression in HepG2 cells. Additionally, treatment with harmaline significantly increased the expression of caspase- 8 and caspase- $8 / 3$ activity. The results from the present study suggest that harmaline suppresses the viability, but induces the apoptosis, of human liver carcinoma cells through upregulation of the p53/p21 and Fas/FasL signaling pathways.
\end{abstract}

\section{Introduction}

Human Liver Cancer (HLC) is a malignant tumor of the digestive system, typically with a poor prognosis, and its mortality rate ranks in third place worldwide of all cancer-associated mortalities (1). Male morbidity is higher compared with female morbidity (1). A report from 2006 revealed that 662,000 patients succumb to HLC annually (2). The morbidity of HLC varies across regions; Eastern and Southeast Asia, a number of Western Pacific islands, and Saharan and Southern Africa have high morbidity rates compared with other countries. The morbidity rate of HLC in Asia is $\sim 70 \%$, and the corresponding morbidity rates of Eastern and Southern

Correspondence to: Dr Minpeng Li, Department of Liver Surgery, The First Affiliated Hospital of Guangxi University of Traditional Chinese Medicine, 89-9 Dongge Road, Nanning, Guangxi 530023, P.R. China

E-mail: lanxuncong73@126.com

Key words: harmaline, liver carcinoma, p53, p21, Fas/FasL
Europe, the Caribbean, Central America and Western Asia are close behind; the morbidity rates of other countries are lower in comparison $(3,4)$.

Tumors arise from aberrations in the cell cycle; mutations in a number of cell cycle-associated genes may result in altered expression and activities of other cell cycle-associated genes, leading to tumor development (4). Abnormalities associated with the $\mathrm{G}_{1} / \mathrm{S}$ checkpoint serve an important role in tumor initiation, as DNA replication and repair and take place during the $\mathrm{G}_{1} / \mathrm{S}$ phase. Cyclin D1, cellular tumor antigen p53 (p53), cyclin-dependent kinase inhibitor 1 (p21) and signal transducer and activator of transcription 3 serve important roles in the regulation of the $G_{1} / S$ phase of the cell cycle $(5,6)$.

Apoptosis is part of the normal life cycle of cells, and is a way to regulate the stability of cell populations (7). Apoptosis maintains the turnover of normal cells and eliminates abnormal cells in vivo; however, abnormal apoptosis is associated with the occurrence of a number of diseases (8). Tumor necrosis factor receptor superfamily member 6 (Fas) and Fas ligand (FasL) are transmembrane proteins that are present on the surface of cells (9). When Fas on the surface of one cell binds to FasL on the membrane of another cell, the cell that expresses Fas undergoes apoptosis. The Fas/FasL signaling pathway is the primary method of mediating liver cell apoptosis $(10,11)$. Therefore, Fas/FasL signaling pathway abnormalities and their association with the occurrence and progression of HLC require further investigation.

Over the last 20 years, a number of studies have investigated the potential anticancer effects of Chinese herbs and extracts, including harmaline, which is an active ingredient extracted from the fleabane seeds of renascent herbs. Harmaline exhibits numerous clinical effects, including protection from radiation, reduction of inflammation, analgesia, antipruritic effects, immunosuppression, relief from psoriasis and antitumor effects (12). The antitumor effects of harmaline, first studied in the 1970s (12), are of particular interest for the current study and other studies. A previous study revealed that harmaline exhibits a number of antitumor effects and has a low risk of producing toxic side effects (13). Harmaline has been demonstrated to have antitumor effects in gastric carcinoma in vivo and in vitro (14). Therefore, in the present study, the anticancer and apoptosis-promoting 
effects of harmaline were investigated in human liver carcinoma cells.

\section{Materials and methods}

Cell culture. Human liver carcinoma (HepG2) cells were obtained from the Animal Centre of Guangxi University of Chinese Traditional Medicine (Nanning, Guangxi, China) and cultured in Dulbecco's modified Eagle's medium (DMEM) supplemented with $10 \%$ fetal bovine serum (FBS; both Gibco, Thermo Fisher Scientific, Inc., Waltham, MA, USA), $100 \mathrm{U} / \mathrm{ml}$ penicillin and $100 \mu \mathrm{g} / \mathrm{ml}$ streptomycin (Thermo Fisher Scientific Inc.) in a humidified incubator with $5 \% \mathrm{CO}_{2}$ at $37^{\circ} \mathrm{C}$.

Cell viability assay. HepG2 cells $\left(1 \times 10^{3}\right)$ were seeded in a 96-well plate and treated with $0-10 \mu \mathrm{M}$ of harmaline (Sigma-Aldrich; Merck KGaA, Darmstadt, Germany) for 12, 24 and $48 \mathrm{~h}$ in a humidified incubator with $5 \% \mathrm{CO}_{2}$ at $37^{\circ} \mathrm{C}$. Following incubation, $20 \mu \mathrm{l}$ of MTT $(0.5 \mathrm{mg} / \mathrm{ml})$ was added to the wells, and the plates were subsequently incubated at $37^{\circ} \mathrm{C}$ for $4 \mathrm{~h}$. Following incubation, $150 \mu \mathrm{l}$ dimethyl sulfoxide was added to each well prior to incubation for a further $20 \mathrm{~min}$ at $37^{\circ} \mathrm{C}$. The absorbance of the plates at $490 \mathrm{~nm}$ was subsequently recorded using a PowerWave HT microplate spectrophotometer (BioTek Instruments, Inc., Winooski, VT, USA). The structural formula of harmaline is illustrated in Fig. 1.

Flow cytometry. HepG2 cells $\left(1 \times 10^{6}\right)$ were seeded in a 6-well plate and treated with $0-10 \mu \mathrm{M}$ harmaline for $48 \mathrm{~h}$ in a humidified incubator with $5 \% \mathrm{CO}_{2}$ at $37^{\circ} \mathrm{C}$. HepG2 cells were washed in PBS, re-suspended in binding buffer from a Annexin V-fluorescein isothiocyanate (FITC)/propidium iodide kit (BD Biosciences, San Jose, CA, USA) and stained using $5 \mu \mathrm{l}$ Annexin V-FITC and $5 \mu \mathrm{l}$ propidium iodide (BD Biosciences) for $15 \mathrm{~min}$ in the dark at room temperature, according to the manufacturer's protocol. The percentage of apoptotic cells was measured using a flow cytometer (COULTER ${ }^{\circledR}$ EPICS $^{\circledR}$ ALTRA $^{\mathrm{TM}}$ Flow Cytometer; Beckman Coulter, Inc., Brea, CA, USA) and CellQuest software 3.0 (Bio-Rad Laboratories, Inc., Hercules, CA, USA).

Caspase-8/3 activity. HepG2 cells $\left(1 \times 10^{3}\right)$ were seeded into 96-well plates and treated with $0-10 \mu \mathrm{M}$ of harmaline for $48 \mathrm{~h}$ in a humidified incubator with $5 \% \mathrm{CO}_{2}$ at $37^{\circ} \mathrm{C}$. $\mathrm{HepG} 2$ cells $\left(1 \times 10^{6}\right)$ were seeded onto a 6 -well plate and treated with 0-10 $\mu \mathrm{M}$ harmaline for $48 \mathrm{~h}$ in a humidified incubator with $5 \% \mathrm{CO}_{2}$ at $37^{\circ} \mathrm{C}$. HepG 2 cells were lyzed in radioimmunoprecipitation assay buffer (Beyotime Institute of Biotechnology, Haimen, China). Total protein was quantified using a BCA assay kit (Beyotime Institute of Biotechnology), and $5 \mu \mathrm{g} / \mathrm{lane}$ of total protein was incubated with the chromogenic substrates Ac-IETD-pNA (caspase-8; catalog no., C1152; Beyotime Institute of Biotechnology) and Ac-DEVD-pNA (caspase-3; catalog no., C1116; Beyotime Institute of Biotechnology) at $37^{\circ} \mathrm{C}$ for $1 \mathrm{~h}$ in the dark. The absorbance was subsequently recorded using a PowerWave HT microplate spectrophotometer at $405 \mathrm{~nm}$.

Western blot analysis. HepG2 cells $\left(1 \times 10^{6}\right)$ were seeded into a 6-well plate and treated with $0-10 \mu \mathrm{M}$ harmaline for $48 \mathrm{~h}$ in a humidified incubator with $5 \% \mathrm{CO}_{2}$ at $37^{\circ} \mathrm{C}$. HepG2 cells were

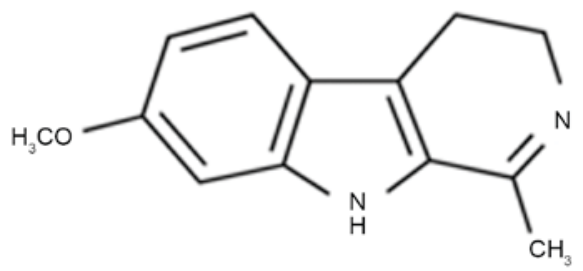

Figure 1. Chemical structure of harmaline.

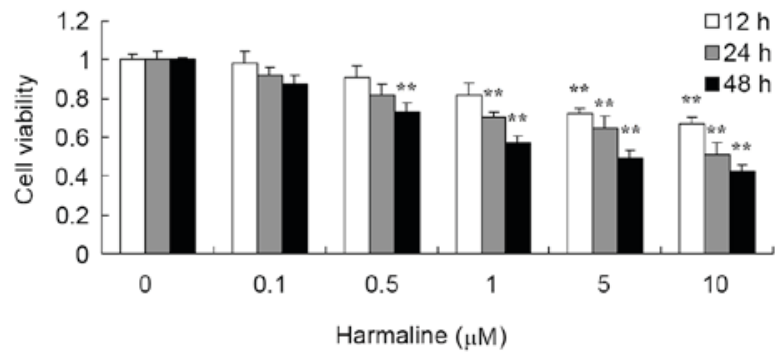

Figure 2. Harmaline decreases the viability of HepG2 cells.** $\mathrm{P}<0.01$ vs. the negative control group ( $0 \mu \mathrm{M}$ of harmaline).

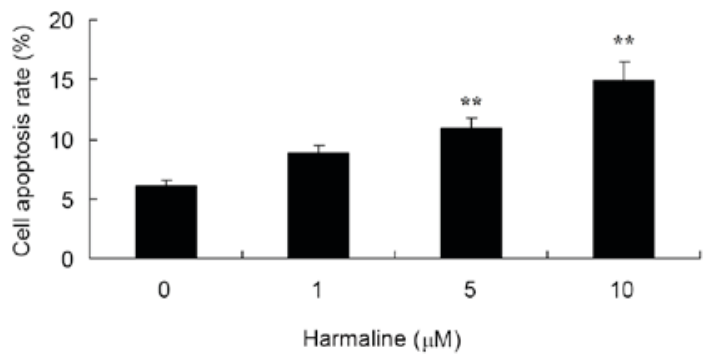

Figure 3. Harmaline increases the apoptotic rate of HepG2 cells. ${ }^{* *} \mathrm{P}<0.01$ vs. the negative control group ( $0 \mu \mathrm{M}$ of harmaline).

lyzed in radioimmunoprecipitation assay buffer (Beyotime Institute of Biotechnology, Haimen, China). Total protein was quantified using a BCA assay kit (Beyotime Institute of Biotechnology), and $50 \mu \mathrm{g} /$ lane of total protein was loaded and run on a $12 \%$ gel using SDS-PAGE. Separated proteins were transferred to a nitrocellulose membrane (Thermo Fisher Scientific, Inc.). The membrane was blocked with $5 \%$ non-fat milk in Tris-buffered saline-0.1\% Tween (TBST) for $1 \mathrm{~h}$ at $37^{\circ} \mathrm{C}$ and incubated with anti-p53 (cat. no. sc-55476; dilution, 1:300), anti-p21 (cat. no. sc-271532; dilution, 1:300) anti-Fas (cat. no. sc-8009; dilution, 1:300), anti-FasL (cat. no. sc-33716; dilution, 1:300), anti-caspase-8 (cat. no., sc-7890; dilution, 1:300) (all Santa Cruz Biotechnology, Inc., Dallas, TX, USA) and anti-GAPDH (cat. no., AG019; dilution, 1:2,000, Beyotime Institute of Biotechnology) antibodies overnight at $4^{\circ} \mathrm{C}$. The membrane was washed with TBST and incubated with a goat anti-rabbit horseradish peroxidase-conjugated secondary antibody (cat. no., A0239; dilution, 1:5,000; Beyotime Institute of Biotechnology) for $1 \mathrm{~h}$ at $37^{\circ} \mathrm{C}$. Protein bands detected using an BeyoECL Plus (Beyotime Institute of Biotechnology) and analyzed using Bio-Rad Laboratories Quantity One software 3.0 (Bio-Rad Laboratories, Inc., Hercules, CA, USA). This experiment was repeated in triplicate. 

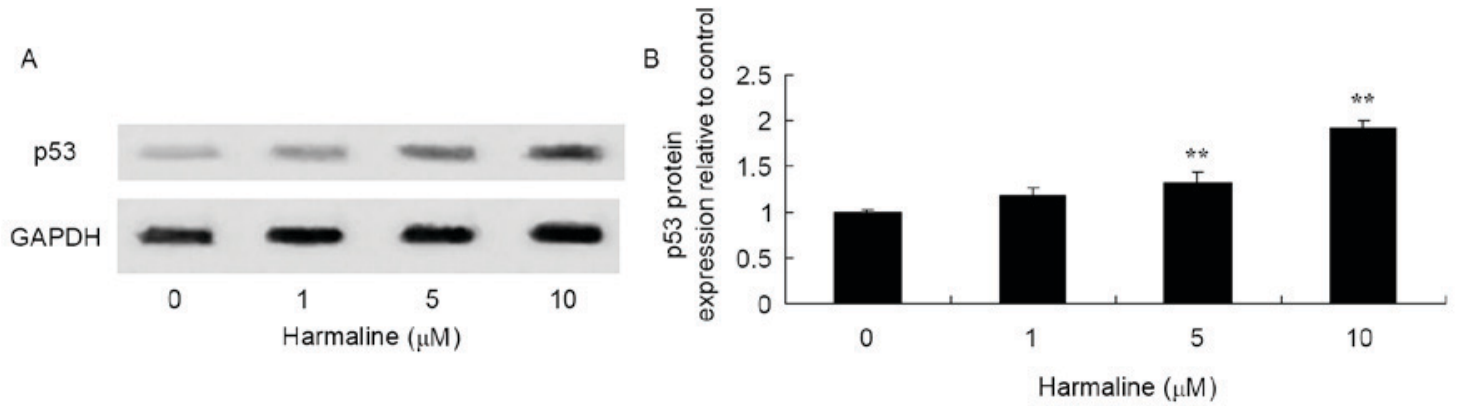

Figure 4. Harmaline increases p53 protein expression in HepG2 cells. (A) Western blot analysis of p53 expression. (B) Statistical analysis of p53 protein expression $(\mathrm{n}=3){ }^{* *} \mathrm{P}<0.01$ vs. the negative control group $(0 \mu \mathrm{M}$ of harmaline). $\mathrm{p} 53$, cellular tumor antigen $\mathrm{p} 53$.
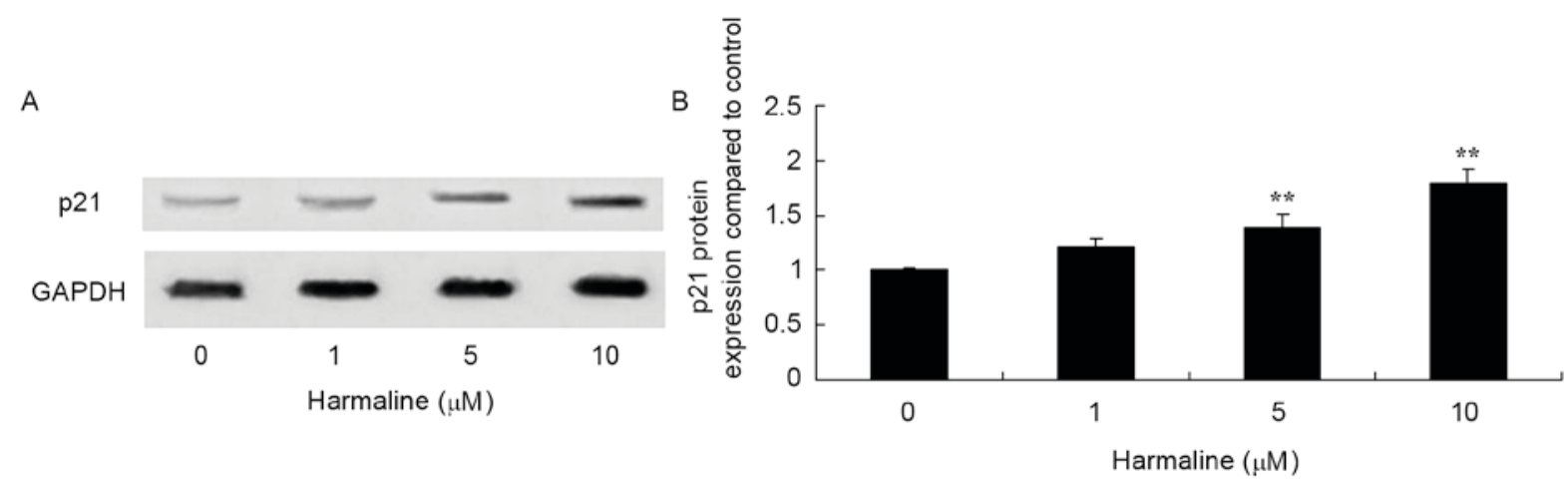

Figure 5. Harmaline increases p21 protein expression in HepG2 cells. (A) Western blot analysis of p21 expression. (B) Statistical analysis of p21 protein expression $(\mathrm{n}=3){ }^{* *} \mathrm{P}<0.01$ vs. the negative control group $(0 \mu \mathrm{M}$ of harmaline). p21, cyclin-dependent kinase inhibitor 1 .

A

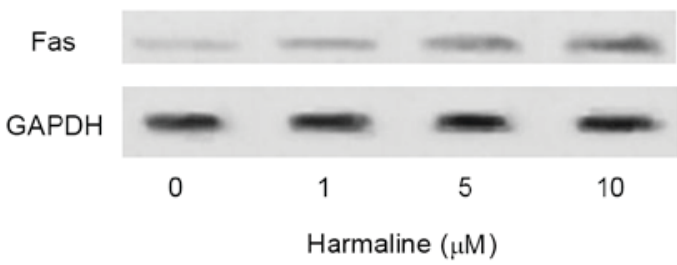

홍

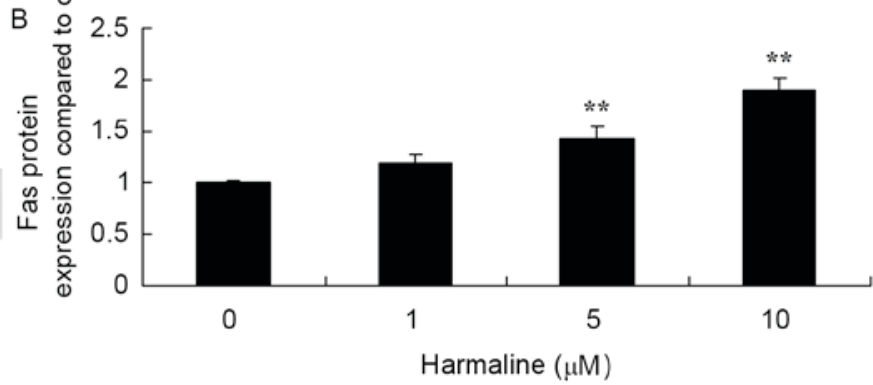

Figure 6. Harmaline increases Fas protein expression in HepG2 cells. (A) Western blot analysis of Fas expression (B) Statistical analysis of Fas protein expression $(\mathrm{n}=3) .{ }^{* *} \mathrm{P}<0.01$ vs. the negative control group $(0 \mu \mathrm{M}$ of harmaline). Fas, tumor necrosis factor receptor superfamily member 6.

Statistical analysis. All results are presented as the mean $\pm \mathrm{SD}$ using SPSS 19.0 (IMB Corp., Armonk, NY, USA). Data were analyzed using one-way repeated measures analysis of variance followed by Duncan's multiple comparison tests. $\mathrm{P}<0.05$ was considered to indicate a statistically significant difference.

\section{Results}

Harmaline decreases Hep 62 cell viability. Following treatment with $0-10 \mu \mathrm{M}$ harmaline for 12,24 or $48 \mathrm{~h}, \mathrm{HepG} 2$ cell viability was analyzed using an MTT assay. Harmaline decreased the viability of HepG2 cells in a time- and dose-dependent manner (Fig. 2). Following treatment with 5 and $10 \mu \mathrm{M}$ harmaline, the viability of HepG2 cells was significantly decreased at 12,24 and $48 \mathrm{~h}$ compared with the untreated negative control group $(\mathrm{P}<0.01)$. Additionally, $1 \mu \mathrm{M}$ harmaline significantly decreased the viability of HepG2 cells at 24 and $48 \mathrm{~h}$ (both $\mathrm{P}<0.01$ ), and $0.5 \mu \mathrm{M}$ harmaline significantly decreased the viability at $48 \mathrm{~h}$ $(\mathrm{P}<0.01)$.

Harmaline increases HepG2 cell apoptosis. Following treatment with $0-10 \mu \mathrm{M}$ of harmaline for $48 \mathrm{~h}$, HepG2 cell apoptosis was analyzed by flow cytometry. Doses of 5 and 
A

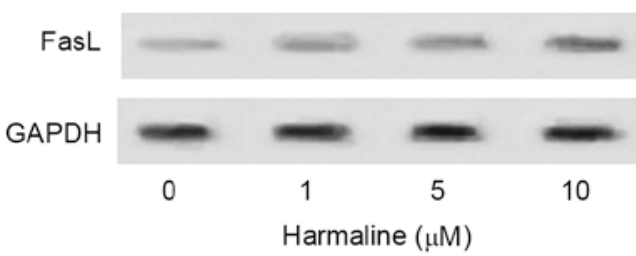

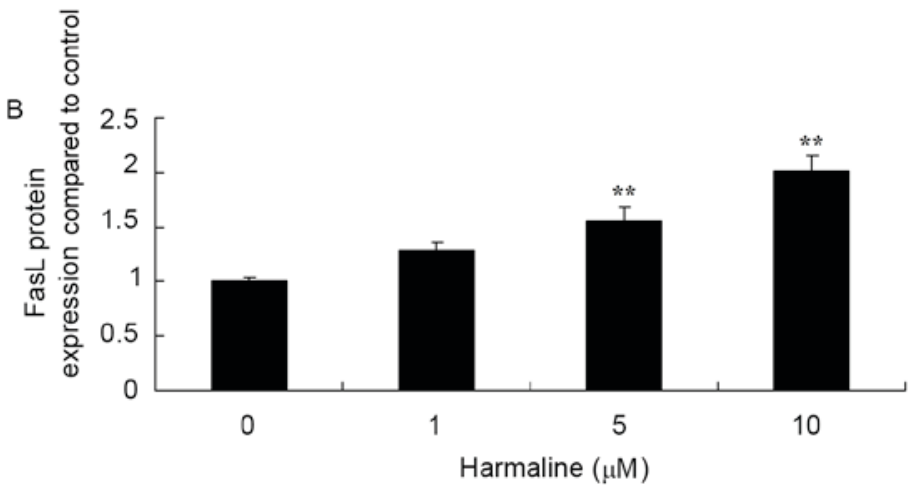

Figure 7. Harmaline increases FasL protein expression in HepG2 cells. (A) Western blot analysis of FasL expression (B) Statistical analysis of FasL protein expression $(\mathrm{n}=3) .{ }^{* *} \mathrm{P}<0.01$ vs. the negative control group $(0 \mu \mathrm{M}$ of harmaline). FasL, tumor necrosis factor receptor superfamily member 6 ligand.

A

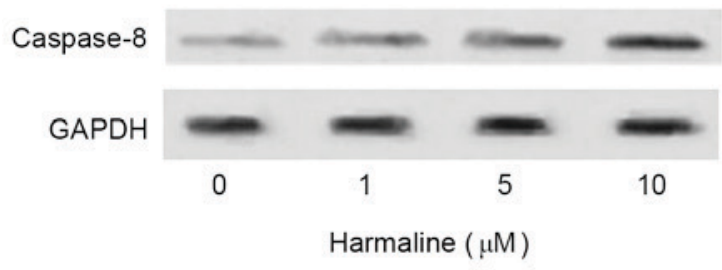

B

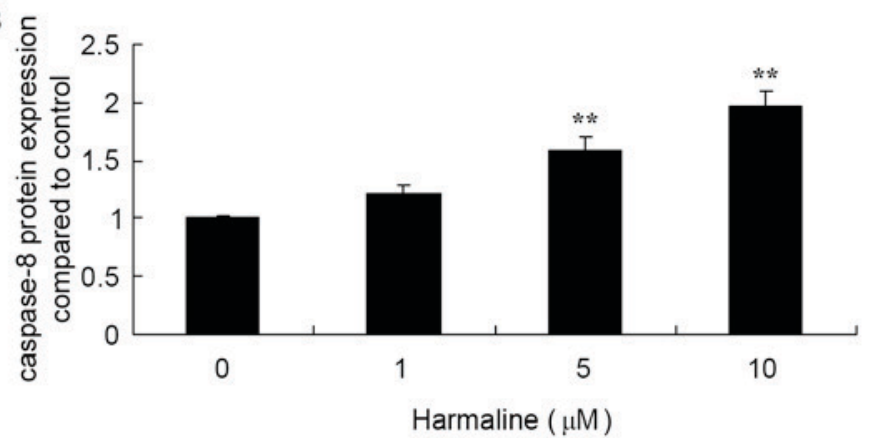

Figure 8. Harmaline increases caspase-8 protein expression in HepG2 cells. (A) Western blot analysis of caspase-8 expression (B) Statistical analysis of caspase- 8 protein expression $(\mathrm{n}=3) .{ }^{* * *} \mathrm{P}<0.01$ vs. the negative control group $(0 \mu \mathrm{M}$ of harmaline).
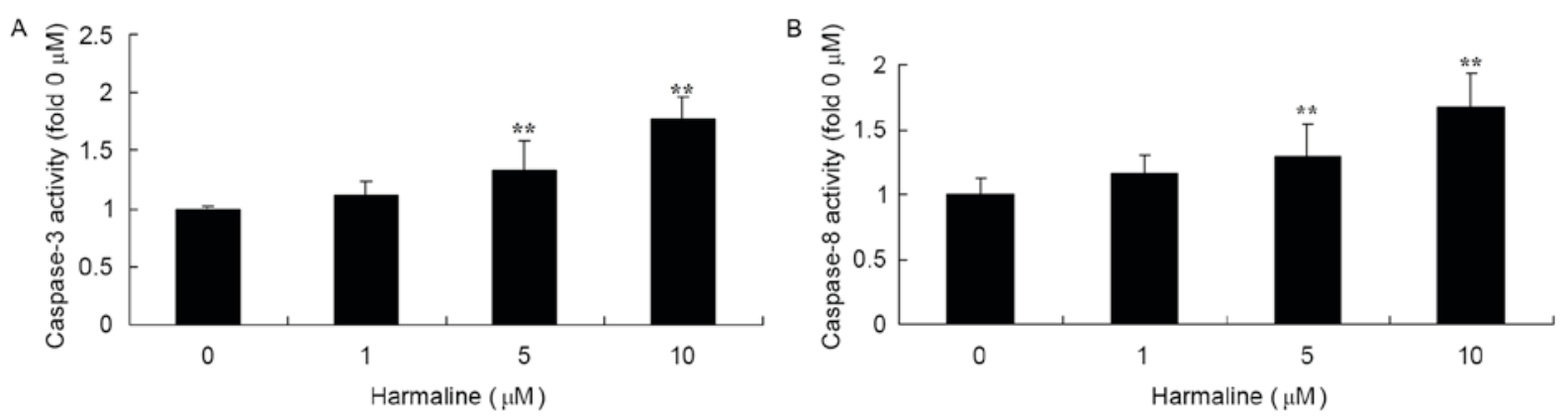

Figure 9. Harmaline increases (A) caspase- 3 and (B) caspase- 8 activity in HepG2 cells. ${ }^{* *} \mathrm{P}<0.01$ vs. the negative control group $(0 \mu \mathrm{M}$ of harmaline).

$10 \mu \mathrm{M}$ harmaline significantly increased the cell apoptosis rate of HepG2 cells compared with the untreated negative control group (Fig. 3; $\mathrm{P}<0.01$ ).

Harmaline increases HepG2 cell p53, p21, Fas and FasL expression. Western blot analysis was performed to assess the effect of harmaline on p53, p21, Fas, FasL and caspase-8 protein expression in HepG2 cells. Compared with the negative control, treatment with 5 and $10 \mu \mathrm{M}$ harmaline for $48 \mathrm{~h}$ significantly increased p53, p21, Fas and FasL protein expression in HepG2 cells compared with the untreated negative control group (Figs. 4-7; $\mathrm{P}<0.01$ ). These results indicate that the p53/p21 and Fas/FasL signaling pathways serve a role in the anticancer effect of harmaline.
Harmaline increases caspase-8 expression and caspase-3/-8 activity in HepG2 cells. In order to explore the underlying molecular mechanisms of harmaline-induced cell apoptosis, the expression and activity of caspase-3/-8 was measured in HepG2 cells following harmaline treatment using a western blot analysis and an ELISA, respectively. Doses of 5 and $10 \mu \mathrm{M}$ harmaline significantly increased caspase- 8 protein expression (Fig. 8; $\mathrm{P}<0.01$ ) and caspase-3/-8 activity (Fig. 9; $\mathrm{P}<0.01)$ compared with the untreated negative control group.

\section{Discussion}

The morbidity rate of HLC is rising, therefore the development of treatments that inhibit the occurrence and development of 
HLC are required (15). The development of HLC is a complex and relatively slow, and there is no definitive pathological definition of HLC in the clinic (16). Therefore, investigating the changes in gene expression that are associated with HLC may aid in the diagnosis and inhibition of HLC occurrence and development (17). The results from the present study demonstrate that harmaline significantly decreases the viability and significantly increases the apoptosis rate of $\mathrm{HepG} 2$ cells.

The gene that encodes p53 is a tumor suppressor gene located on human chromosome $17 \mathrm{p}$. The $\mathrm{p} 53$ protein is a $53 \mathrm{kDa}$ protein that serves a role in several core cellular processes, including transcription, DNA repair, the cell cycle, genome stability, chromosomal separation, apoptosis and vascularization. Under normal conditions, p53 is expressed at a low level (18). Mutations in the gene encoding p53 have been identified in various types of human cancer, including HLC (18). Activation of the gene encoding p53 is associated with changes in various cell activities and surroundings, including the following: Increased sensitivity to DNA damage induced by UV-light, gamma rays, X-rays and topoisomerase; cell stress (anoxia and decreased cell adhesion) (18-20). Following DNA damage and prior to DNA replication, the development of neoplasia can be prevented through DNA repair, apoptosis and/or $\mathrm{G}_{1} / \mathrm{S}$ arrest, which the p53 signaling pathway can regulate $(18,19)$. The results from the present study demonstrated that harmaline significantly increases p53 protein expression in HepG2 cells, indicating that harmaline affects the p53 signaling pathway.

Following DNA damage and p53 activation, transcription of p21 is induced, which arrests cells in $\mathrm{G}_{1}(21)$. In addition, p21 may act synergistically with proliferating cell nuclear antigen to inhibit DNA synthesis (22). However, p21 can stabilize the interaction between cyclin-dependent kinase (CDK)-4/6 and cyclin D, promoting the formation of cyclin $\mathrm{D} / \mathrm{CDK}$ complexes (23). p21 is the transcriptional target of p53 and serves an essential role in mediating the effects DNA damage, including adriamycin- and gamma radiation-induced DNA damage, in addition to cell growth inhibition (24). Overexpression of p21 leads to the arrest of cells in $G_{1} / G_{2}$ or $\mathrm{S}$ phase (24). However, cells lacking p21 cannot mediate the effects of p53 upregulation following DNA damage (25). In addition, the consistent expression of p21 and p53 is important in $\mathrm{G}_{2}$ following DNA injury. The results from the present study demonstrate that harmaline significantly increases p 21 protein expression in HepG2 cells, indicating that harmaline affects the p21 signaling pathway.

Membrane-bound FasL and soluble FasL may be cross-linked with Fas to form a trimer, leading to the subsequent interaction of the Fas molecule DD (DD) with other DDs in the trimer. This subsequently leads to the activation of caspase- 8 zymogens by the DD of Fas-associated protein with death domain (FADD), which activates caspase- 8 and results in the apoptosis of cells that express Fas (10). Fas/FasL-mediated apoptosis serves an important physiological role in cancer (10). The results from the present study demonstrated that harmaline significantly increases Fas, FasL and caspase- 8 protein expression and activity in HepG2 cells.

A previous study identified Fas expression in HLC and liver para-carcinoma; however, compared with liver para-carcinoma, the level of cirrhosis in HLC was significantly reduced (7).
Fas expression in the non-cancerous hepatic tissues of patients with HLC is upregulated compared with that in HLC cells (8). Compared with patients with Fas-negative diseases, the number of intrahepatic lesions in patients with HLC is significantly decreased (26). Survival times of patients with increased levels of Fas in cancer tissues or sera is improved compared to those without (26). Fas/FasL-mediated apoptosis in HLC cells is inhibited through downregulated or short Fas expression. In this circumstance, tumor cell apoptosis is reduced, and therefore tumor cells proliferate, acquire survival and metastasize (27).

The results of the present study demonstrated that harmaline significantly increases caspase- $8 / 3$ activity in HepG2 cells. Wang et al (26) demonstrated that harmaline induces $\mathrm{G}_{2} / \mathrm{M}$ cell cycle arrest and apoptosis through upregulation of Fas/FasL in SGC-7901 gastric cancer cells. In addition, the data from the current study demonstrated that harmaline significantly inhibits the viability and increases the apoptosis of HepG2 cells, which was associated with increased expression of p53/p21, Fas/FasL and caspase-8, and increased caspases- $8 / 3$ activity. These results indicate that harmaline affects the p53/p21 and Fas/FasL signaling pathways, and thus may be a potential drug for treating liver cancer.

\section{References}

1. Lee SB, Park YI, Dong MS and Gong YD: Identification of $2,3,6$-trisubstituted quinoxaline derivatives as a Wnt $2 / \beta$-catenin pathway inhibitor in non-small-cell lung cancer cell lines. Bioorg Med Chem Lett 20: 5900-5904, 2010.

2. Jarnagin WR, Schwartz LH, Gultekin DH, Gönen M, Haviland D, Shia J, D'Angelica M, Fong Y, Dematteo R, Tse A, et al: Regional chemotherapy for unresectable primary liver cancer: Results of a phase II clinical trial and assessment of DCE-MRI as a biomarker of survival. Ann Oncol 20: 1589-1595, 2009.

3. Heo J, Reid T, Ruo L, Breitbach CJ, Rose S, Bloomston M, Cho M, Lim HY, Chung HC, Kim CW, et al: Randomized dose-finding clinical trial of oncolytic immunotherapeutic vaccinia JX-594 in liver cancer. Nat Med 19: 329-336, 2013.

4. Qu K, Xu X, Liu C, Wu Q, Wei J, Meng F, Zhou L, Wang Z, Lei L and Liu P: Negative regulation of transcription factor FoxM1 by p53 enhances oxaliplatin-induced senescence in hepatocellular carcinoma. Cancer Lett 331: 105-114, 2013.

5. Wang H, Ye Y, Chui JH, Zhu GY, Li YW, Fong DW and Yu ZL: Oridonin induces G2/M cell cycle arrest and apoptosis through MAPK and p53 signaling pathways in HepG2 cells. Oncol Rep 24: 647-651, 2010.

6. Chao CH, Chen CM, Cheng PL, Shih JW, Tsou AP and Lee YH: DDX3, a DEAD box RNA helicase with tumor growth-suppressive property and transcriptional regulation activity of the p21waf1/cip1 promoter, is a candidate tumor suppressor. Cancer Res 66: 6579-6588, 2006

7. Li MS, Ma QL, Chen Q, Liu XH, Li PF, Du GG and Li G: Alpha-fetoprotein triggers hepatoma cells escaping from immune surveillance through altering the expression of Fas/FasL and tumor necrosis factor related apoptosis-inducing ligand and its receptor of lymphocytes and liver cancer cells. World J Gastroenterol 11: 2564-2569, 2005.

8. Guo CL, Yang XH, Cheng W, Xu Y, Li JB, Sun YX, Bi YM, Zhang L and Wang QC: Expression of Fas/FasL in CD8+ T and CD3+ Foxp3+ Treg cells-relationship with apoptosis of circulating CD8+ T cells in hepatocellular carcinoma patients. Asian Pac J Cancer Prev 15: 2613-2618, 2014.

9. Chang WT, Hsieh BS, Cheng HL, Lee KT and Chang KL: Progesterone augments epirubicin-induced apoptosis in HA22T/VGH cells by increasing oxidative stress and upregulating Fas/FasL. J Surg Res 188: 432-441, 2014.

10. Jung YJ, Kim YJ, Kim LH, Lee SO, Park BL, Shin HD and Lee HS: Putative association of Fas and FasL gene polymorphisms with clinical outcomes of hepatitis B virus infection. Intervirology 50: 369-376, 2007. 
11. Nakamura M, Nagano H, Sakon M, Yamamoto T, Ota H, Wada H, Damdinsuren B, Noda T, Marubashi S, Miyamoto A, et al: Role of the Fas/FasL pathway in combination therapy with interferon-alpha and fluorouracil against hepatocellular carcinoma in vitro. J Hepatol 46: 77-88, 2007.

12. Nasehi M, Meskarian M, Khakpai F and Zarrindast MR: Harmaline-induced amnesia: Possible role of the amygdala dopaminergic system. Neuroscience 312: 1-9, 2016.

13. Amin B, Malekzadeh M, Heidari MR and Hosseinzadeh $\mathrm{H}$ : Effect of Crocus sativus extracts and its active constituent safranal on the harmaline-induced tremor in mice. Iran J Basic Med Sci 18: 449-458, 2015.

14. Sasaki K, Bower JM and Llinás R: Multiple purkinje cell recording in rodent cerebellar cortex. Eur J Neurosci 1: 572-586, 1989.

15. Drozdov I, Bornschein J, Wex T, Valeyev NV, Tsoka S and Malfertheiner P: Functional and topological properties in hepatocellular carcinoma transcriptome. PLoS One 7: e35510, 2012.

16. George $\mathrm{J}$ and Patel T: Noncoding RNA as therapeutic targets for hepatocellular carcinoma. Semin Liver Dis 35: 63-74, 2015.

17. Yang H, Peng YF, Ni HM, Li Y, Shi YH, Ding WX and Fan J: Basal autophagy and feedback activation of akt are associated with resistance to metformin-induced inhibition of hepatic tumor cell growth. PLoS One 10: e0130953, 2015.

18. Ashur-Fabian O, Har-Zahav A, Shaish A, Wiener Amram H, Margalit O, Weizer-Stern O, Dominissini D, Harats D, Amariglio N and Rechavi G: apoB and apobec1, two genes key to lipid metabolism, are transcriptionally regulated by $\mathrm{p} 53$. Cell Cycle 9: 3761-3770, 2010

19. Lu Q, Teng GJ, Zhang Y, Niu HZ, Zhu GY, An YL, Yu H, Li GZ, Qiu DH and Wu CG: Enhancement of p53 gene transfer efficiency in hepatic tumor mediated by transferrin receptor through trans-arterial delivery. Cancer Biol Ther 7: 218-224, 2008.
20. Formigari A, Gregianin E and Irato P: The effect of zinc and the role of p53 in copper-induced cellular stress responses. J Appl Toxicol 33: 527-536, 2013.

21. Zhang MF, Zhang ZY, Fu J, Yang YF and Yun JP: Correlation between expression of $\mathrm{p} 53$, p21/WAF1, and MDM2 proteins and their prognostic significance in primary hepatocellular carcinoma. J Transl Med 7: 110, 2009.

22. Farah IO, Begum RA and Ishaque AB: Differential protection and transactivation of P53, P21, Bcl2, PCNA, cyclin $\mathrm{G}$, and MDM2 genes in rat liver and the HepG2 cell line upon exposure to pifithrin. Biomed Sci Instrum 43: 116-121, 2007.

23. Sheahan S, Bellamy CO, Dunbar DR, Harrison DJ and Prost S: Deficiency of G1 regulators P53, P21Cip1 and/or pRb decreases hepatocyte sensitivity to TGFbeta cell cycle arrest. BMC Cancer 7: 215, 2007.

24. Liu T, Qin W, Hou L and Huang Y: MicroRNA-17 promotes normal ovarian cancer cells to cancer stem cells development via suppression of the LKB1-p53-p21/WAF1 pathway. Tumour Biol 36: 1881-1893, 2015.

25. Ou X, Lu Y, Liao L, Li D, Liu L, Liu H and Xu H: Nitidine chloride induces apoptosis in human hepatocellular carcinoma cells through a pathway involving p53, p21, Bax and Bcl-2. Oncol Rep 33: 1264-1274, 2015.

26. Wang $\mathrm{Y}$, Wang $\mathrm{C}$, Jiang $\mathrm{C}$, Zeng $\mathrm{H}$ and $\mathrm{He} \mathrm{X}$ : Novel mechanism of harmaline on inducing $\mathrm{G} 2 / \mathrm{M}$ cell cycle arrest and apoptosis by up-regulating Fas/FasL in SGC-7901 cells. Sci Rep 5: 18613 , 2015.

27. Vekemans K, Braet F and Wisse E: DiO-labeled CC531s colon carcinoma cells traverse the hepatic sinusoidal endothelium via the Fas/FasL pathway. J Gastrointest Surg 8: 371-372, 2004. 